\title{
Optimization of Physical and Functional Properties of Sorghum-Bambara Groundnut Extrudates
}

\author{
David Iordehiin Gbenyi ${ }^{1}$, Iro Nkama ${ }^{2} \&$ Mamudu Halidu Badau ${ }^{3}$ \\ ${ }^{1}$ Department of Food Science and Technology, The Federal Polytechnic, P.M.B. 35, Mubi, Adamawa State, \\ Nigeria \\ ${ }^{2}$ Department of Food Science and Technology, University of Nigeria, Nsukka, Nigeria \\ ${ }^{3}$ Department of Food Science and Technology, University of Maiduguri, P.M.B. 1069, Maiduguri, Nigeria \\ Correspondence: David Iordehiin Gbenyi, Department of Food Science and Technology, The Federal Polytechnic, \\ P.M.B. 35, Mubi, Adamawa State, Nigeria. E-mail: digbenyi@yahoo.com; davidgbenyi@gmail.com
}

\author{
Received: January 18, 2016 Accepted: March 15, 2016 Online Published: March 27, 2016 \\ doi:10.5539/jfr.v5n2p81 URL: http://dx.doi.org/10.5539/jfr.v5n2p81
}

\begin{abstract}
Blends of sorghum and Bambara groundnut flour at 90:10, 80:20 and 70:30 ratios respectively, were extruded at $20 \%, 22.5 \%$ and $25 \%$ moisture levels and $120^{\circ} \mathrm{C}, 140^{\circ} \mathrm{C}$ and $160^{\circ} \mathrm{C}$ barrel temperatures using a single-screw extruder. Response surface methodology with central composite face-centered (CCF) design was used to model the viscosity, water absorption index (WAI) water solubility index (WSI), sectional expansion index (SEI), bulk density (BD), apparent specific volume (ASV) and mass flow rate of the extrudates. The viscosity, WAI, WSI, SEI, BD, ASV and MFR of extrudates varied from 8.38 to $18.78 \mathrm{Nsm}^{-2}, 5.30$ to $6.21 \mathrm{~g} / \mathrm{g}$ water, 10.5 to $21 \%$, 2.55 to $5.1,0.223$ to $0.499 \mathrm{~g} / \mathrm{cm}^{3}, 4.15$ to $6.55 \mathrm{~cm}^{3}$, and 1.19 to $2.3 \mathrm{~g} / \mathrm{s}$ respectively. The $\mathrm{R}^{2}$ values were 0.83 , $0.71,0.55,0.61,0.66,0.77$ and 0.61 respectively with a non-significant lack of fit; except for viscosity. Plots of residuals against fitted values showed that residuals were randomly scattered in all cases, thus validating the empirical models for the responses. The optimum amount of Bambara groundnut flour, feed moisture and extrusion temperature were established for viscosity, WAI, SEI, BD, ASV and MFR of the extrudates. Feed moisture had the most effect on extrudates functional and physical properties followed by extrusion temperature.
\end{abstract}

Keywords: extrusion, functional properties, optimization, Bambara groundnut, response surface

\section{Introduction}

Sorghum is one of the staple crops for human consumption in large areas of the world. Nigeria is the largest producer of sorghum in Africa and third largest the world over (USDA, 2015). Sorghum is composed of $84.0 \%$ carbohydrates, $11 \%$ protein, $2.5 \%$ fat, $2.2 \%$ crude fibre, and $1.6 \%$ ash (Shobha et al., 2008). It is however underutilized in modern food processing technologies in Nigeria. Gomez et al. (1988) has reported on extrusion cooking of three sorghum varieties containing different amounts of amylose. According to the authors, decreasing the moisture content during extrusion resulted in increased expansion and decreased density and breaking strength of extrudates. Extrusion is a process which combines several unit operations including mixing, cooking, kneading, shearing, shaping and forming (Lewis, 1987). Usually the food is compressed and worked to form a semi-solid mass. This is then forced through a restricted opening (the die) at the discharge end of the screw. The main purpose of extrusion is to increase variety of foods in the diet by producing a range of products with different shapes, textures, colours, and flavours from basic ingredients (Lewis, 1987).

Bambara groundnut (Vigna subterranea L. Verde) is an indigenous African grain legume grown over the ages. It is the third most important grain legume after groundnut and cowpea in the sub-Saharan Africa (Ocran, 1998). It makes very little demand on the soil and has high nutritive value with $63 \%$ carbohydrate, $19 \%$ protein and $6.5 \%$ oil (Goli, 1997). It also contains minerals like calcium (95.5-99.0 mg/100g), iron (5.1-9.0mg/100g), potassium $(11,447-14,355 \mathrm{mg} / 100 \mathrm{~g})$ and sodium $(2.9-10.6 \mathrm{mg} / 100 \mathrm{~g})$ (Karikari et al., 1997). It is extensively grown in Nigeria (Oguntunde, 1985; Enwere, 1998) but grossly underutilized. The annual world production is 330,000 metric tonnes, $45-50 \%$ of which are produced in West Africa (Nigeria, Niger, Burkina Faso, chad, Cote d'Ivoire, Ghana and Mali) (PROTA, 2006). The crop has a number of production advantages in that it can yield on poor soils with little rainfall as well as produce substantial yields under better conditions (Mkandawire, 2007). In 
2008, it was estimated that Nigeria produced between 100,000 and 168,700 metric tonnes from and area 15350 hectares (NFRA, 2008).

Commercial canning of Bambara groundnut in gravy is a successful industry in countries such as Zimbabwe and Ghana (Mkandawire, 2007). Immature pods can be boiled and consumed as snacks. The fresh seeds can also be cracked open to remove the skins. The seeds are then wet milled, mixed with salt, spices and red palm oil, wrapped in leaves before cooking to produce moin-moin or akpukpa in Nigeria. At maturity however, the seeds can be pounded or milled using attrition mills, into flour and used to make a stiff porridge (Nsima), or mixed with spices and salt, wrapped into leaves and cooked to produce moin-moin or akpupa (Olapade and Adetunji, 2007).

Many Nigerians do not have access to animal protein because of the high cost of fish and meat. This has necessitated the need to develop low-cost, high protein-energy foods (Nkama, 1994). The utilization of extrusion cooking and supplementation of sorghum flour with plant protein such as Bambara groundnut in the production of a breakfast cereal is likely to increase protein consumption of Nigerians.

The production of breakfast cereals in Nigeria currently gives less attention to utilization of extrusion technology and locally available raw materials like sorghum and Bambara groundnut. Breakfast cereals available in the Nigerian market are mostly produced from maize. This work was intended to assess the effect of extrusion cooking conditions on the physical and functional properties of breakfast cereal from red sorghum (Chakalari red), supplementation of the breakfast cereal with Bambara groundnut and to optimize the functional and physical properties of the extrudates using response surface methodology.

\section{Materials and Methods}

\subsection{Procurement of Raw Materials}

The red sorghum variety (Chakalari red), was obtained from Maiduguri Monday market. Bambara groundnut was obtained from the Mubi main market.

\subsection{Preparation of Sorghum Flour}

About $15 \mathrm{~kg}$ of sorghum grains were cleaned using a laboratory aspirator (Vegvari Ferenc Type OB125, Hungary) to remove stalks, chaff, leaves and other foreign matter. They were then washed with treated tap water in plastic basins and sun dried on mats for 2 days (at $38^{\circ} \mathrm{C}$ and relative humidity of $27.58 \%$ ) to $12 \%$ moisture. This was then dehulled using a commercial rice dehuller (Konching 1115, China) and milled using an attrition mill (Imex GX 160, Japan). The flour was sieved to pass mesh number 25 (BS, 1985) before packing in polythene bags for further use.

\subsection{Preparation of Bambara groundnut Flour}

About $3 \mathrm{~kg}$ of Bambara groundnut was first washed with clean water and then dried in a Chirana convection air oven (Model: HS 201A, Hungary) at $80^{\circ} \mathrm{C}$ to $12 \%$ moisture content and milled (Imex GX 160, Japan) into flour which was sieved to pass mesh number 25 (BS, 1985) before packing in polythene bags for further use (Filli et al., 2010).

\subsection{Blending of Sorghum Flour with Bambara Groundnut Flour and Moisture Adjustment}

Sorghum flour was blended with Bambara groundnut flour in varying proportions $(10 \%, 20 \%, 30 \%$ Bambara groundnut). The individual moisture contents of the Bambara groundnut and sorghum flours were determined (on dry weight basis) using the hot air oven method (Egan et al., 1981) and then the total moisture of the blends adjusted to the desired level according to Zasypkin and Tung-Ching (1998), using the formula below. The blends were mixed using a laboratory mixer (Hobert, Model: A200) and the moisture allowed to equilibrate for one hour before extrusion.

$$
\begin{aligned}
& \mathrm{C}_{\mathrm{bf}}=\left[\mathrm{r}_{\mathrm{bf}} \times \mathrm{M} \times(100-\mathrm{w})\right] /\left[100 \times\left(100-\mathrm{W}_{\mathrm{bf}}\right)\right] \\
& \mathrm{C}_{\mathrm{sf}}=\left[\mathrm{r}_{\mathrm{sf}} \times \mathrm{M} \times(100-\mathrm{w})\right] /\left[100 \times\left(100-\mathrm{W}_{\mathrm{sf}}\right)\right] \\
& \mathrm{W}_{\mathrm{x}}=\mathrm{M}-\mathrm{C}_{\mathrm{bf}}-\mathrm{C}_{\mathrm{sf}}
\end{aligned}
$$

Where $\mathrm{C}_{\mathrm{bf}}$ is the mass of Bambara groundnut flour $(\mathrm{g})$; $\mathrm{C}_{\mathrm{sf}}$, the mass of sorghum flour $(\mathrm{g})$; $\mathrm{sf}$, and $\mathrm{bf}_{\mathrm{bf}}$ are sorghum flour and Bambara groundnut flour respectively; $r_{b f}$ and $r_{s f}$ are the Bambara groundnut flour (\%) and sorghum flour (\%) respectively; $\mathrm{M}$, the total mass of the blend $(\mathrm{g})$; $\mathrm{w}$ is the moisture content of final blend $(\%)$; $\mathrm{W}_{\mathrm{x}}$ is weight of water added $(\mathrm{g}) ; \mathrm{W}_{\mathrm{bf}}$, the moisture content of Bambara groundnut flour (\%); while $\mathrm{W}_{\mathrm{sf}}$ is the moisture content of sorghum flour $(\%)$. 


\subsection{The Extrusion Process}

Extrusion cooking was done in a single screw extruder (Model: Brabender Duisburg DCE-330), equipped with a variable speed DC drive unit and strain gauge type torque meter. The extruder was fed manually through a screw operated conical hopper. The hopper which is mounted vertically above the end of the extruder is equipped with a screw which was adjusted to $139 \mathrm{rpm}$. The samples were extruded at a screw speed of $200 \mathrm{rpm}, 2.0 \mathrm{~mm}$ die diameter, 2 bars pressure and a length/diameter ratio of 20:1. Experimental samples were collected when steady state (constant temperature and torque) was achieved. Variables considered were feed composition, feed moisture content and temperature of extrusion. Fresh extrudates were kept on stainless steel work benches overnight to dry. They were then packaged in polythene bags prior to analysis.

\subsection{Determination of Viscosity of Extrudates Paste}

The viscosity of extrudates was determined using the Sine-wave Vibro Viscometer (SV Series Version 1.12E, A\&D Company Limited, Japan) coupled to a desktop computer. Extrudates were first crushed in a mortar with pestle. About $10 \mathrm{~g}$ of the ground extrudate was transferred to a beaker and made up to $100 \mathrm{~mL}$ with hot water at $60{ }^{\circ} \mathrm{C}$ to give a $10 \%(\mathrm{w} / \mathrm{v})$ concentration (Badau et al., 2006). This was mixed and allowed to stand for $10 \mathrm{~min}$. The content was then transferred into a viscometer cup which was then placed and clamped in position on the stage of the viscometer with clips. The plates of the viscometer were then lowered into the cup containing the sample. The viscosity of the samples was read at $40{ }^{\circ} \mathrm{C}$.

\subsection{Water Absorption Index (WAI) and Water Solubility Index (WSI)}

This was determined according to Beuchat (1977). One gram (1g) of sample was mixed with $10 \mathrm{~mL}$ distilled water for $30 \mathrm{sec}$ in a centrifuge tube. The samples were then allowed to stand at $25^{\circ} \mathrm{C}$ for $30 \mathrm{~min}$ and centrifuged at $55,000 \mathrm{x}$ g for $30 \mathrm{~min}$. The volume of the supernatant in a $10 \mathrm{~mL}$ graduated cylinder was noted. Water absorption index was determined on the residue while the water solubility index was determined on the supernatant.

\subsection{Bulk Density of Extrudates}

Bulk density of the extrudates was determined using the method of Qing-Bo et al. (2005). The diameter of the extrudates was measured using a micrometer screw gauge while the length of extrudates was measured using a rule. Measurements were taken five times in each case and the average values used to calculate bulk density thus:

$$
\text { Bulk density }=\frac{4 a^{0}}{\pi D^{2} L}
$$

Where $\mathrm{a}^{\mathrm{o}}, \mathrm{D}$, and $\mathrm{L}$ are the mass, diameter and length of extrudates, respectively.

\subsection{Sectional Expansion Index (SEI)}

This was determined according to the procedures of Alvarez-Martinez et al. (1988). The following equation was used.

$$
\text { Sectional Expansion Index }=\left(\frac{D e}{D}\right)^{2}
$$

Where $\mathrm{D}_{\mathrm{e}}$ is the diameter of extrudate and $\mathrm{D}$ is the diameter of the die $(\mathrm{mm})$.

\subsection{Apparent Specific Volume}

This was determined according to the procedure of Alvarez- Martinez et al. (1988). The diameter of the extrudates was measured using a micrometer screw gauge while the length of extrudates was measured using a rule. Measurements were taken five times in each case and the average value used. The following equation was used:

$$
\text { Apparent Specific Volume }=\frac{\pi D_{e}^{2} L_{s e}}{4}
$$

Where:

$$
\begin{aligned}
& \mathrm{L}_{\mathrm{se}}=\text { mean length of } 1 \mathrm{~g} \text { of extrudate material } \\
& \mathrm{D}_{\mathrm{e}}=\text { Diameter of the extruded material }
\end{aligned}
$$

\subsection{Mass Flow Rate (MFR)}

This was determined according to Nwabueze and Iwe (2006) and Oke et al. (2010). When steady state was 
reached, as determined by constant torque and barrel temperature, a timer (stop watch) was started immediately. Samples of extrudates flowing out of the extruder die orifice were collected after 60 s interval. The mean weight of three of such collections was calculated for each run in grams per minute.

\subsection{Experimental Design}

The Central Composite Face-Centered Design (CCFC) used in this work was produced using MINITAB 14 statistical software. Table 1 shows the process variables and their levels used in the design. The experimental matrix used in this study, based on central composite face-centered design, is as shown in Table 2 . The experimental space had fourteen star points and six central points, making a total of twenty runs. The data obtained from the study was fitted to the second-order polynomial regression model (Annor et al., 2009) of the form:

$$
\mathrm{Y}=\mathrm{b}_{\mathrm{o}}+\mathrm{b}_{1} \mathrm{X}_{1}+\mathrm{b}_{2} \mathrm{X}_{2}+\mathrm{b}_{3} \mathrm{X}_{3}+\mathrm{b}_{11}\left(\mathrm{X}_{1}\right)^{2}+\mathrm{b}_{22}\left(\mathrm{X}_{2}\right)^{2}+\mathrm{b}_{33}\left(\mathrm{X}_{3}\right)^{2}+\mathrm{b}_{12} \mathrm{X}_{1} \mathrm{X}_{2}+\mathrm{b}_{13} \mathrm{X}_{1} \mathrm{X}_{3}++\mathrm{b}_{23} \mathrm{X}_{2} \mathrm{X}_{3}+\varepsilon
$$

Where $X_{1}, X_{2}$ and $X_{3}$ are feed composition (cowpea flour), feed moisture and barrel temperature, respectively; $b_{0}$ is the regression constant; $b_{1}, b_{2}$ and $b_{3}$ are linear regression terms; $b_{11}, b_{22}$ and $b_{33}$ are quadratic regression terms; $\mathrm{b}_{12}, \mathrm{~b}_{13}$ and $\mathrm{b}_{23}$ are the cross-product regression terms; $\varepsilon$ is the error term.

Table 1. Independent variables and their levels of replication

\begin{tabular}{ccccc}
\hline \multicolumn{2}{c}{ Parameters } & \multicolumn{3}{c}{ Levels of replication } \\
Cowpea flour (\%), & $\mathrm{X}_{1}$ & -1 & 0 & 30 \\
\hline Feed Moisture (\%), & $\mathrm{X}_{2}$ & 10 & 20 & 25 \\
Temperature $\left({ }^{\circ} \mathrm{C}\right)$, & $\mathrm{X}_{3}$ & 20 & 22.5 & 160 \\
\hline
\end{tabular}

Table 2. Central composite face centered (CCF) design matrix and the independent variables in their natural forms

\begin{tabular}{|c|c|c|c|c|c|c|}
\hline Runs & $\mathrm{X}_{1}$ & $\mathrm{X}_{2}$ & $\mathrm{X}_{3}$ & $\begin{array}{c}\text { Feed composition } \\
(\%)\end{array}$ & $\begin{array}{c}\text { Feed moisture } \\
(\%)\end{array}$ & Extrusion temp. $\left({ }^{\circ} \mathrm{C}\right)$ \\
\hline 1. & -1 & -1 & -1 & 10 & 20 & 120 \\
\hline 2. & +1 & -1 & -1 & 30 & 20 & 120 \\
\hline 3. & -1 & +1 & -1 & 10 & 25 & 120 \\
\hline 4. & + & +1 & -1 & 30 & 25 & 120 \\
\hline 5. & -1 & -1 & +1 & 10 & 20 & 160 \\
\hline 6. & +1 & -1 & +1 & 30 & 20 & 160 \\
\hline 7. & -1 & +1 & +1 & 10 & 25 & 160 \\
\hline 8. & +1 & +1 & +1 & 30 & 25 & 160 \\
\hline 9. & -1 & 0 & 0 & 10 & 22.5 & 140 \\
\hline 10. & +1 & 0 & 0 & 30 & 22.5 & 140 \\
\hline 11. & 0 & -1 & 0 & 20 & 20 & 140 \\
\hline 12. & 0 & +1 & 0 & 20 & 25 & 140 \\
\hline 13. & 0 & 0 & -1 & 20 & 22.5 & 120 \\
\hline 14. & 0 & 0 & +1 & 20 & 22.5 & 160 \\
\hline 15. & 0 & 0 & 0 & 20 & 22.5 & 140 \\
\hline 16. & 0 & 0 & 0 & 20 & 22.5 & 140 \\
\hline 17. & 0 & 0 & 0 & 20 & 22.5 & 140 \\
\hline 18. & 0 & 0 & 0 & 20 & 22.5 & 140 \\
\hline 19. & 0 & 0 & 0 & 20 & 22.5 & 140 \\
\hline 20. & 0 & 0 & 0 & 20 & 22.5 & 140 \\
\hline
\end{tabular}

Key: $\mathrm{X}_{1}=$ feed composition, $\mathrm{X}_{2}=$ feed moisture, $\mathrm{X}_{3}=$ extrusion temperature 


\subsection{Statistical Analysis}

MINITAB version 14 statistical analysis software was used in the statistical analysis of data. Analysis of variance (ANOVA) was used to establish statistical significance of the model. Numerical optimization and interactive graphs were used to optimize the various input variables and responses. Graphical residual analysis (NIST/SEMATECH, 2006) was used to establish the validity of the empirical models.

\section{Results and Discussion}

\subsection{Water Absorption Index (WAI) and Water Solubility Index (WSI)}

The water absorption index is a measure of the volume occupied by the extrudates starch after swelling in excess water, which maintains the integrity of starch in aqueous dispersion (Qing-Bo et al., 2005). Water absorption and water solubility indices are important indicators of the degree of gelatinization (cooking) (Kebede et al., 2010). The water absorption index of the extrudates varied from 5.30 to $6.21 \mathrm{~g} / \mathrm{g}$ water (Table not shown). The highest water absorption index was from the sample with $10 \%$ Bambara groundnut flour, $20 \%$ feed moisture, extruded at $120^{\circ} \mathrm{C}$. The water absorption index of the extrudates decreased sharply with increase in feed moisture and increased as the extrusion temperature increased (Figure 1a). It also decreased sharply as the feed composition increased and increased with the extrusion temperature. Filli et al. (2013) similarly reported WAI for extruded fura from millet-Bambara groundnut blends which varied from 4.67 to $6.76 \mathrm{~g} / \mathrm{g}$ water. Kebede et al. (2010) also observed that extrudates from red and white tef generally absorbed water over 4 to 5 times their weight. Lower water absorption capacity is desirable for making thinner gruels (Nicole et al., 2010). The optimum WAI (5.8 g/g water) in this work was obtained at $15.05 \%$ Bambara groundnut flour, $21 \%$ feed moisture and $133^{\circ} \mathrm{C}$ extrusion temperature (Table 4). Extrusion temperature showed the most effect on WAI. The WSI ranged from 4.42 to $6.89 \%$. The highest WSI value was from the sample with $10 \%$ Bambara groundnut, $20 \%$ feed moisture, extruded at $160^{\circ} \mathrm{C}$. The water solubility index of the extrudates decreased sharply with increase in feed composition and also decreased progressively (Figure 2) as the feed moisture was increased. Filli et al. (2013) made similar reports on WSI of extruded fura from millet-Bambara groundnut blends. Kebede et al. (2010) however reported lower values ( 0.023 to $0.0316 \mathrm{~g} / 100 \mathrm{~g}$ ) of WSI for extrudates from red and white tef. The effect of feed composition, feed moisture and extrusion temperature on the regression parameters of WAI and WSI of the Sorghum-Bambara groundnut extrudates is shown in Table 3 . The WAI was significantly $(\mathrm{p}<0.05)$ affected by the positive interaction effects of feed composition and extrusion temperature. The WSI was significantly $(p<0.05)$ influenced by the negative linear effect of feed composition. The coefficients of determination $\left(\mathrm{R}^{2}\right)$ for WAI and WSI were 0.71 and 0.55 respectively with a non-significant lack of fit. Malcolmson et al. (1993) and Annor et al. (2009) stated that an $\mathrm{R}^{2}$ of $80 \%(0.80)$ appears excessive for preliminary study and therefore recommended that $\mathrm{R}^{2}$ of $60 \%$ can be used. In this report, 0.60 was adopted for $\mathrm{R}^{2}$ for validation of the models. A high $\mathrm{R}^{2}$ value does not necessarily guarantee that the model fits the data well. The primary tool for most process modeling applications is graphical residual analysis (NIST/SEMATECH, 2006). In this work, the residuals were plotted against fitted values to establish the validity of the empirical models. If the residuals are randomly scattered then, the model fits the data reasonably well. A plot of the residuals against fitted values for WAI is shown in Figure 1(c) while that for the WSI is presented in Figure 2(b). It could be observed that the residuals are randomly scattered about zero. This suggests that the second-order model equation was sufficient in describing the WAI of the extrudates. It however, weakly $\left(\mathrm{R}^{2}=0.55\right)$ described the water solubility index of the extrudates. Water solubility index measures the amount of soluble polysaccharides released from the starch component after extrusion (Ding et al., 2005). Gelatinized or cooked starch polymers in solution can exist in several physical forms such as, trapped in granule remnants, entangled in gelled masses, as individual molecules, recrystallized (retrograded) polymers, and perhaps as combination of the above forms. Processing conditions influence the distribution of these forms and thus the water solubility of the product (Jackson et al., 1990). 
Table 3. Regression coefficients of physical and functional properties of sorghum-Bambara groundnut extrudates

\begin{tabular}{|c|c|c|c|c|c|c|c|}
\hline Coefficients & WAI & WSI & SEI & $\mathrm{BD}$ & ASV & MFR & Viscosity \\
\hline$b_{o}$ & 12.6272 & 34.5271 & 53.2929 & 1.2022 & -116.960 & 7.8132 & -77.866 \\
\hline$b_{1}$ & -0.1081 & $-3.3597^{*}$ & -0.3469 & 0.0314 & -0.2515 & 0.0442 & -0.1410 \\
\hline $\mathrm{b}_{2}$ & -0.1956 & 7.2137 & -2.0511 & -0.1932 & $11.9315^{* *}$ & -0.8901 & -10.092 \\
\hline$b_{3}$ & -0.0371 & -0.9805 & -0.3384 & 0.0111 & -0.0888 & 0.0489 & $2.891 * *$ \\
\hline \multicolumn{8}{|l|}{ Quadratic } \\
\hline$b_{11}$ & -0.0018 & 0.0169 & 0.0028 & -0.0002 & $0.0099 *$ & -0.0006 & -0.0095 \\
\hline$b_{22}$ & 0.0004 & -0.2073 & 0.0248 & 0.0055 & $-0.2648 * *$ & 0.0232 & $0.3038^{*}$ \\
\hline$b_{33}$ & - & 0.0030 & 0.0009 & - & 0.0003 & -0.0002 & $-0.0070 * *$ \\
\hline \multicolumn{8}{|l|}{ Interaction } \\
\hline $\mathrm{b}_{12}$ & 0.0015 & 0.0743 & 0.0079 & -0.0007 & -0.0045 & -0.0018 & $0.0450 *$ \\
\hline $\mathrm{b}_{13}$ & $0.0009 *$ & 0.0069 & 0.0002 & - & -0.0005 & 0.0002 & -0.004 \\
\hline$b_{23}$ & 0.0004 & 0.0025 & 0.0050 & -0.0001 & -0.0004 & -0.0004 & $-0.031 * *$ \\
\hline $\mathrm{R}^{2}$ & 0.710 & 0.551 & 0.609 & 0.659 & 0.773 & 0.612 & 0.830 \\
\hline Adjusted $\mathrm{R}^{2}$ & 0.4449 & 0.1468 & 0.257 & 0.353 & 0.569 & 0.263 & 0.677 \\
\hline Lack of Fit & NS & NS & NS & NS & NS & NS & $*$ \\
\hline
\end{tabular}

Table 4. Optimization of functional and physical properties of sorghum-Bambara groundnut extrudates

\begin{tabular}{ccccc}
\hline Responses & Feed composition (\%) & Feed moisture (\%) & Extrusion temperature $\left({ }^{\circ} \mathrm{C}\right)$ & Optimum \\
\hline WAI & 15.1 & 21.0 & 133 & $5.8 \mathrm{~g} / \mathrm{g} \mathrm{H} \mathrm{H}_{2}$ \\
SEI & 12.0 & 20.0 & 156.6 & 4.5 \\
BD & 19.0 & 21.0 & 135 & $0.32 \mathrm{~g} / \mathrm{cm}^{3}$ \\
ASV & 17.5 & 22.3 & 142 & $5.5 \mathrm{~cm}^{3}$ \\
MFR & 15.5 & 21.02 & 142.5 & $2.0 \mathrm{~g} / \mathrm{s}$ \\
Viscosity & 21.1 & 22.5 & 125 & $12.0 \mathrm{Nsm}^{-2}$ \\
\hline
\end{tabular}

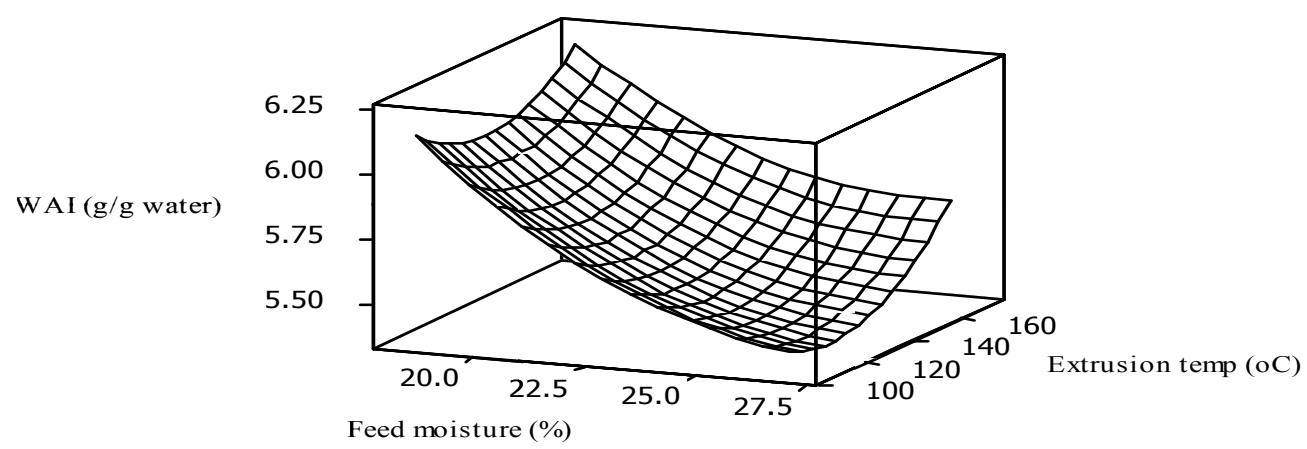

Figure 1(a). Effect of feed moisture and extrusion temperature on water absorption index of sorghum-Bambara groundnut extrudates 


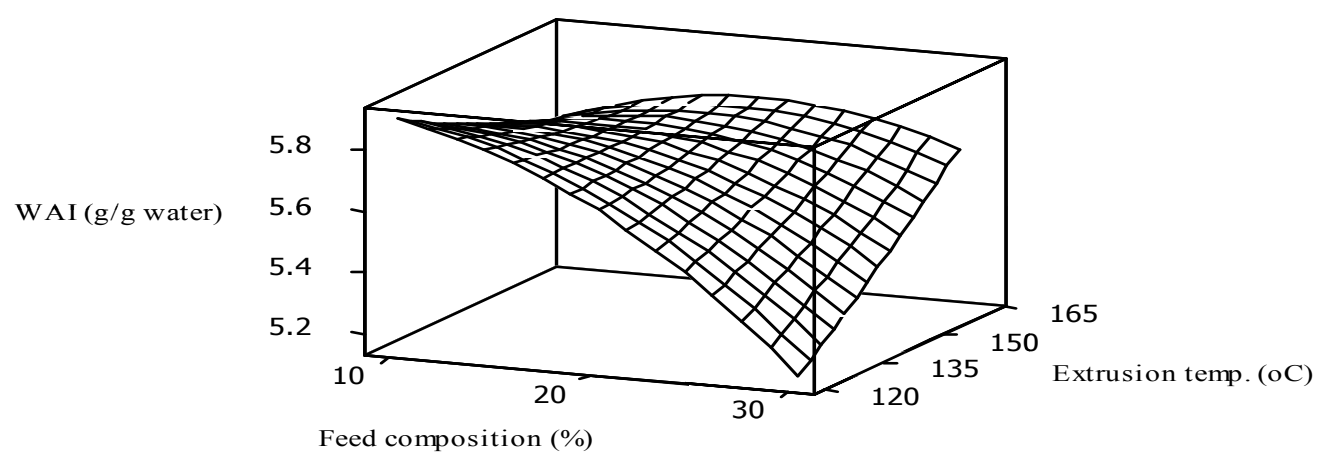

Figure 1(b). Effect of feed composition and extrusion temperature on water absorption index of sorghum-Bambara groundnut extrudates

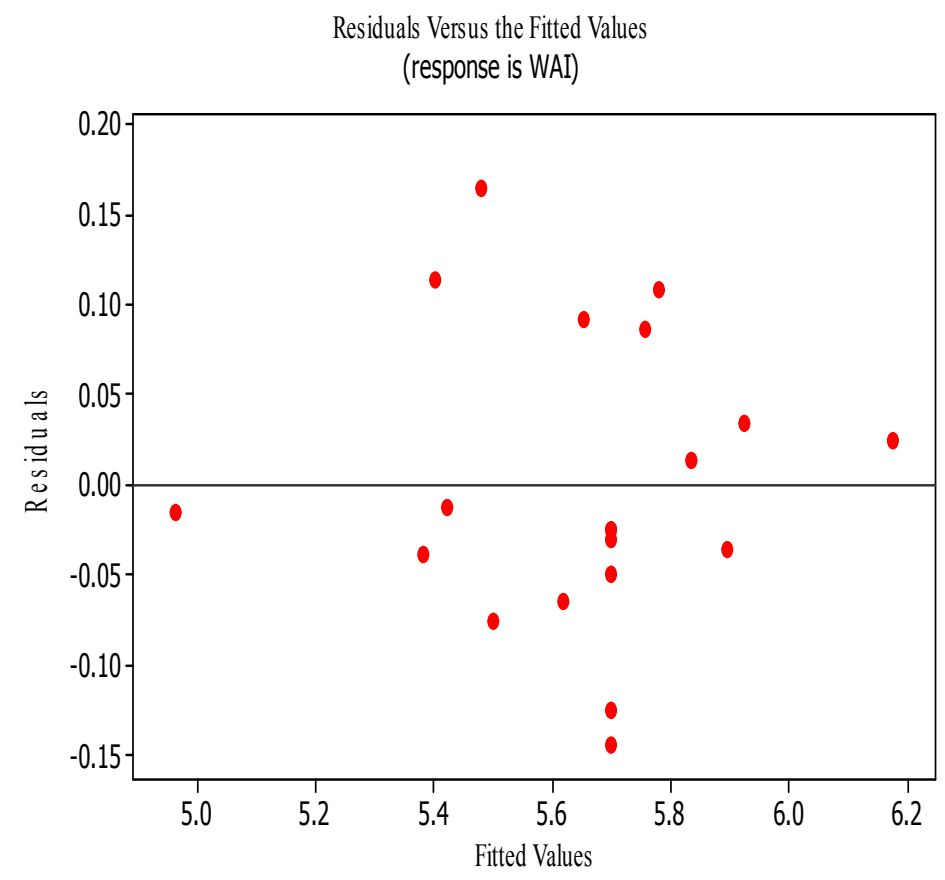

Figure 1(c). Residuals and fitted values of water absorption index of sorghum-Bambara groundnut extrudates

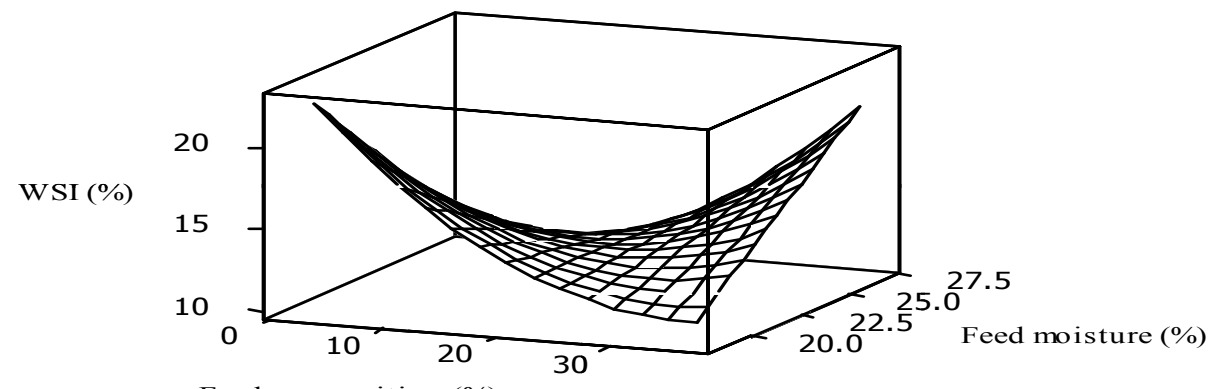

Figure 2(a). Effect of feed moisture and feed composition on water solubility index of sorghum-Bambara groundnut extrudates 


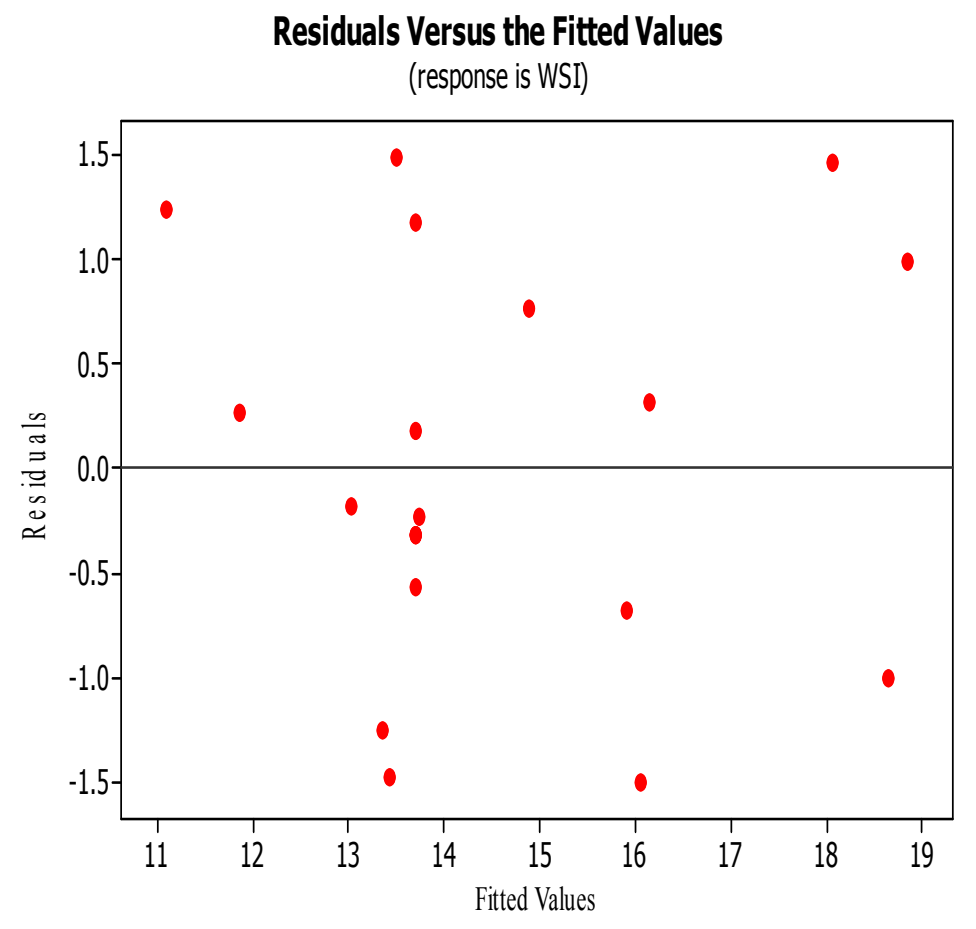

Figure 2(b). Residuals and fitted values of water solubility index of sorghum-Bambara groundnut extrudates

\subsection{Sectional Expansion Index (SEI) and the Bulk Density (BD)}

Expansion ratio is an important characteristic of extruded products being developed as a snack and ready-to-eat product by food industries (Baladran-Quintana et al., 1998). The sectional expansion index of the extrudates varied from 2.55 to 5.1 (Table not shown). The sample with 10\% Bambara groundnut blend and $20 \%$ feed moisture, extruded at $160^{\circ} \mathrm{C}$ showed maximum SEI. The sectional expansion index decreased with increase in feed moisture but increased progressively with increase in extrusion temperature (Figure 3a). The SEI also decreased with increase in feed composition but increased as the extrusion temperature was increased. This is in agreement with Gomez et al. (1988). Similar reports by Kebede et al. (2010) indicated that radial expansion of extruded products from red and white tef flour were significantly $(\mathrm{p}<0.05)$ affected by the feed moisture, barrel temperature and screw speed. Pelembe et al. (2002) similarly observed significantly higher expansion ratios at higher extrusion temperature of $165^{\circ} \mathrm{C}$. The optimum SEI of 4.5 was found at $12 \%$ Bambara groundnut flour, $20 \%$ feed moisture and extrusion temperature of $156.6^{\circ} \mathrm{C}$ (Table 4).

Bulk density is a measure of heaviness of a food material (Oladele \& Aina, 2007). Increase in bulk density is desirable because it offers greater packaging advantage as more quantity may be packed within constant volume (Molina et al., 1983). Low bulk density is however, preferred in infant and weaning foods (Nicole et al., 2010). The $\mathrm{BD}$ of the extrudates varied from 0.223 to $0.499 \mathrm{~g} / \mathrm{cm}^{3}$. The highest BD was observed from the sample with $20 \%$ Bambara groundnut flour, $22.5 \%$ moisture, extruded at $140^{\circ} \mathrm{C}$. The $\mathrm{BD}$ of extrudates increased with increase in feed moisture (Figure 4a). Extrusion temperature had no significant effect on the bulk density of the extrudates. The BD also increased as the feed composition increased. Gomez et al. (1988) also observed that decreasing the moisture content of the feed during extrusion resulted in increased expansion and decreased density. Filli et al. (2013) reported values of BD for extruded fura to range from 0.06 to $0.43 \mathrm{~g} / \mathrm{cm}^{3}$ which is in agreement with the reports in this work. Kebede et al. (2010) found that, BD was significantly reduced (50\%) by barrel temperature followed by feed moisture. Mercier and Feillet (1975) and Suknark et al. (1997) reported similar trend for these indices as a function of the feed moisture. The effect of feed composition, feed moisture and extrusion temperature on the regression parameters of SEI and BD of the sorghum-Bambara groundnut extrudates is shown in Table 3. The SEI and BD were not affected by the linear, quadratic and interaction terms in the model equation. The coefficients of determination $\left(\mathrm{R}^{2}\right)$ for SEI and BD were 0.61 and 0.66 respectively with a non-significant lack of fit. This means $61 \%$ and $66 \%$ of the total variations for SEI and BD respectively, were explained by the empirical model. The bulk density was not influenced by the linear, quadratic and interaction terms in the model. Plots of the residuals against the fitted value for SEI and BD are presented in Figures 3(b) and 4(b). It may be observed that the 
residuals are randomly scattered about the zero line suggesting a good fit for describing both the SEI and BD. The optimum bulk density was $0.32 \mathrm{~g} / \mathrm{cm}^{3}$ at $19 \%$ feed composition and $21 \%$ feed moisture and $135^{\circ} \mathrm{C}$ extrusion temperature.

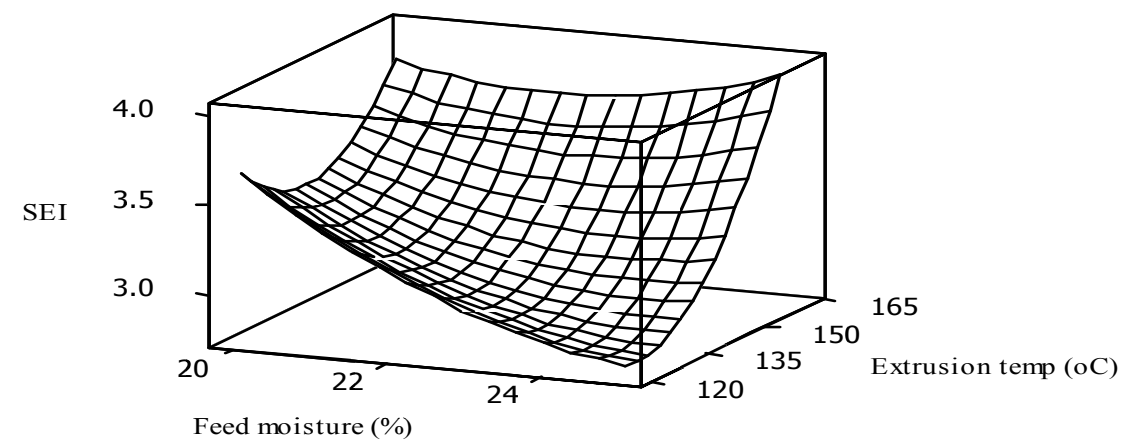

Figure 3(a). Effect of feed moisture and extrusion temperature on sectional expansion index of sorghum-Bambara groundnut extrudates

\section{Residuals Versus the Fitted Values}

(response is SEI)

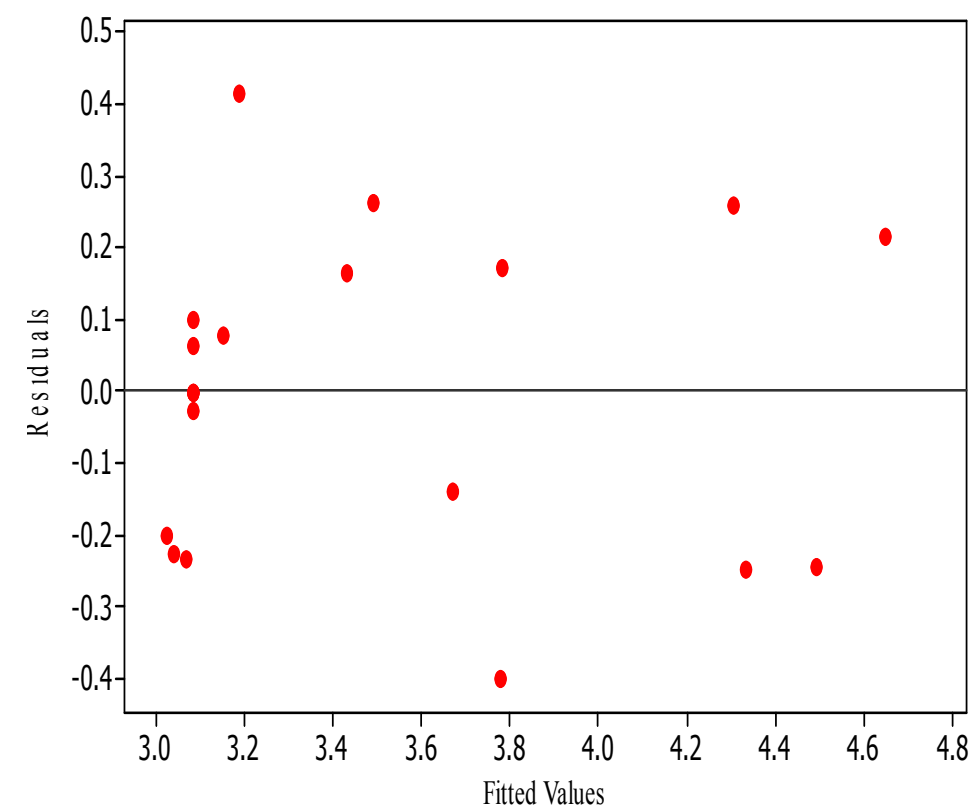

Figure 3(b). Residuals and fitted values of sectional expansion index of sorghum-Bambara groundnut extrudates

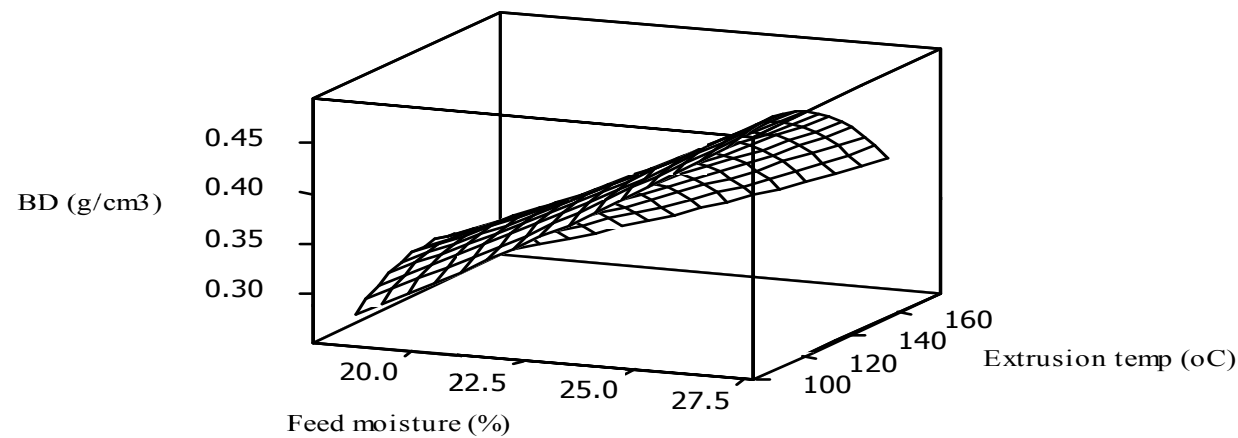

Figure 4(a). Effect of feed moisture and extrusion temperature on bulk density of sorghum-Bambara groundnut extrudates 


\section{Residuals Versus the Fitted Values}

(response is $\mathrm{BD}$ )

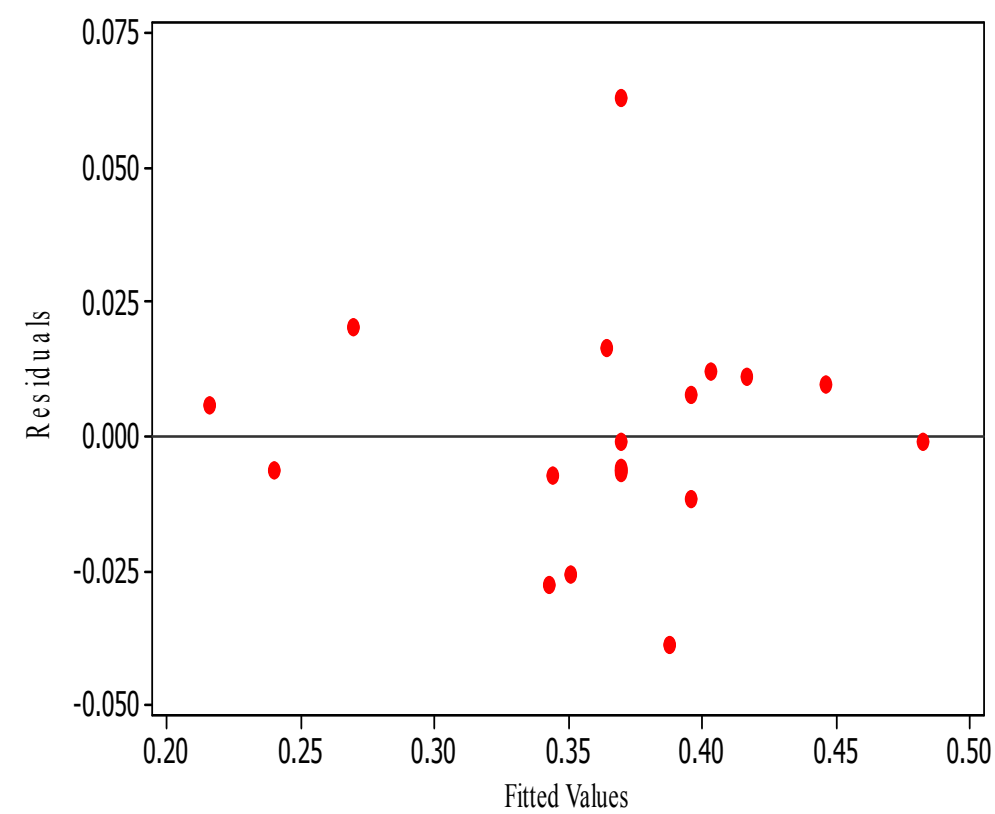

Figure 4(b). Residuals and fitted values of bulk density of sorghum-Bambara groundnut extrudates

\subsection{Apparent Specific Volume (ASV) and Mass Flow Rate (MFR)}

The ASV is directly linked to the degree of expansion of the extrudates. The more expanded the extrudates, the higher the ASV. The apparent specific volume of the extrudates varied from 4.15 to $6.55 \mathrm{~cm}^{3}$. The maximum ASV was from the sample with $10 \%$ Bambara groundnut flour and $22.5 \%$ feed moisture, extruded at $140^{\circ} \mathrm{C}$. The ASV of the extrudates decreased sharply as the feed composition and feed moisture were increased (Figure 5a). This is in agreement with Gomez et al. (1988), Kebede et al. (2010), Filli et al. (2012) and Filli et al. (2013). Apparent specific volume (ASV) like expansion index has a direct link to the rehydration properties of the extrudates. Well expanded products with high ASV rehydrate faster than those with high bulk density (Filli et al., 2012). The optimum ASV was $5.5 \mathrm{~cm}^{3}$ at $17.5 \%$ feed composition, $22.3 \%$ feed moisture and $142^{\circ} \mathrm{C}$ extrusion temperature. Mass flow rate defines the throughput of the process. In other words, it provides information on the amount of extrudate that can be produced within a given period of time. The mass flow rate of the extrudates varied from 1.19 to $2.3 \mathrm{~g} / \mathrm{s}$. Mass flow rate of the extrudates progressively increased as the feed moisture was raised (Figure 6a), while increasing the extrusion temperature led to a progressive decrease in the MFR. Increase in the feed composition caused a marginal increase in the mass flow rate of the extrudates. The regression coefficients of ASV and MFR are presented in Table 3. The coefficients of determination for the ASV and MFR were 0.77 and 0.61 respectively with a non-significant lack of fit. The ASV was significantly $(p<0.01)$ affected by the positive linear effect of feed moisture and the positive quadratic effect of feed composition and negative quadratic effect of feed moisture. The mass flow rate was not influenced by the linear, quadratic and interaction terms in the model. The plots of residuals versus fitted values for the ASV and MFR are shown in Figures 5(b) and 6(b). It can be seen that the residuals are randomly distributed suggesting that the second order model adequately defined these parameters hence it could be used as a predictor for both the ASV and the MFR of the sorghum-Bambara groundnut extrudates (Table 3). The optimum MFR of $2.0 \mathrm{~g} / \mathrm{s}$ was located at $15 \%$ feed composition, 21.0 feed moisture and $142.5^{\circ} \mathrm{C}$ extrusion temperature (Table 4). 


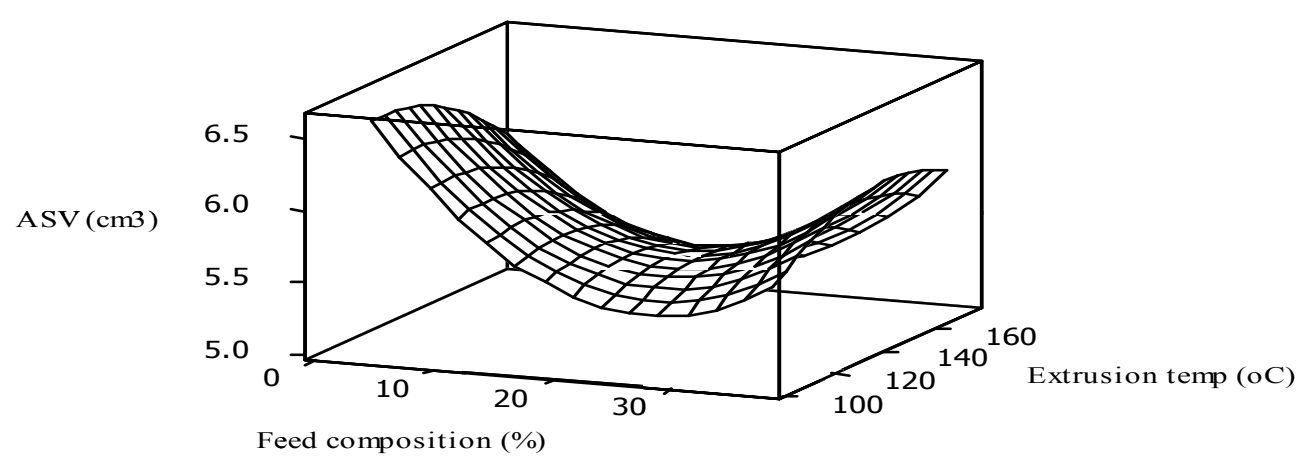

Figure 5(a). Effect of extrusion temperature and feed composition on the ASV of sorghum-Bambara groundnut extrudates

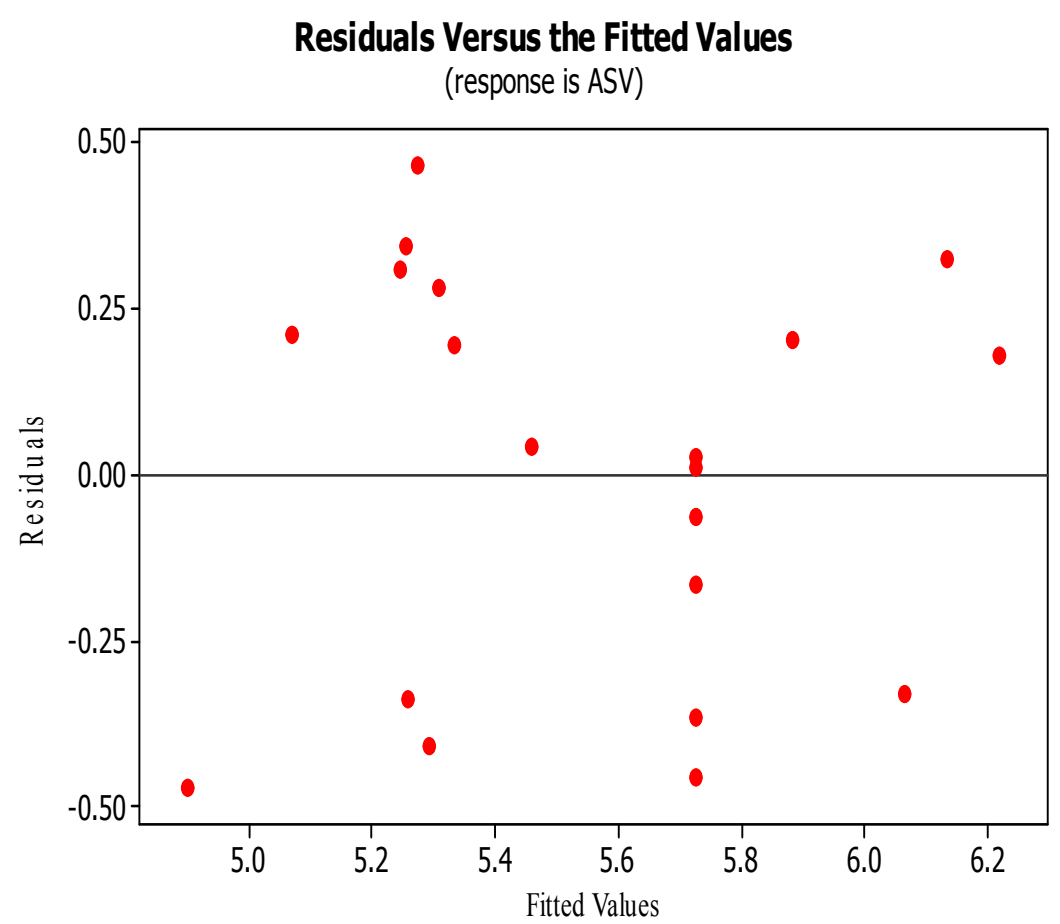

Figure 5(b). Residuals and fitted values of apparent specific volume of sorghum-Bambara groundnut extrudates

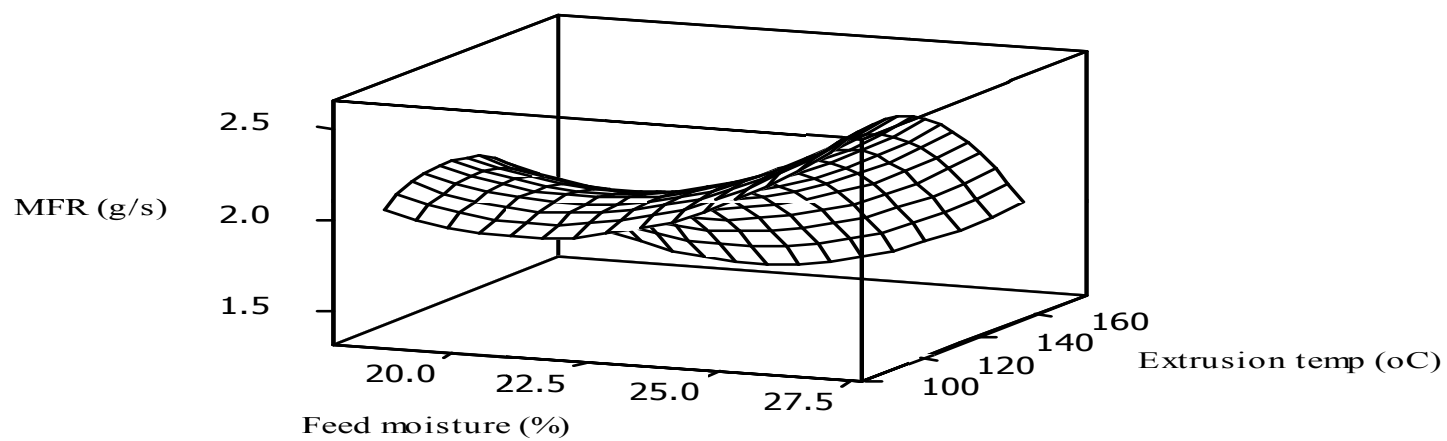

Figure 6(a). Effect of extrusion temperature and feed moisture on MFR of sorghum-Bambara groundnut extrudates 


\section{Residuals Versus the Fitted Values}

(response is MFR)

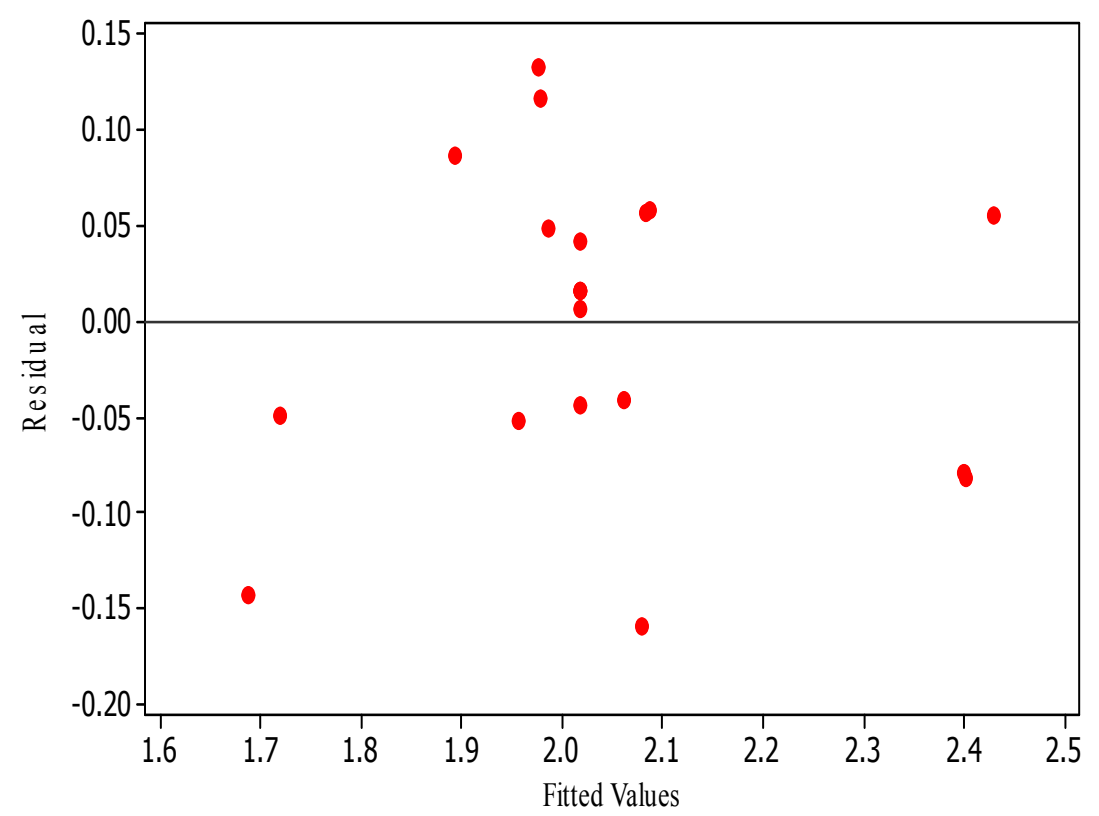

Figure 6(b). Residuals and fitted values of mass flow rate of sorghum-Bambara groundnut extrudates

\subsection{Viscosity}

Viscosity is a measure of resistance to flow. It is an important characteristic of liquid foods in many areas of food processing. The characteristic mouth feel of food products is dependent on their consistency or viscosity (Fellows, 2000). The viscosity of the extrudates varied from 8.38 to $18.78 \mathrm{Nsm}^{-2}$ (Table not shown). Filli et al. (2013) made similar reports on the viscosity of extruded millet-Bambara groundnut fura. This is in agreement with the reports in this work. Maximum viscosity was recorded by the sample with $20 \%$ Bambara groundnut and $20 \%$ feed moisture, extruded at $140^{\circ} \mathrm{C}$. Feed moisture when combined with extrusion temperature caused an increase in the viscosity as the feed moisture was increased, but decreased with increase in extrusion temperature (Figure 7a). Increasing feed composition caused slight increase in viscosity up to a maximum ( $22.5 \%$ feed composition) and began to decrease. Contrary to the findings in this work, Gomez et al. (1988) observed increases in apparent viscosity of atoles from sorghum as extrusion moisture content of the sorghum extrudates decreased. During extrusion cooking, two important reactions (protein denaturation and starch gelatinization) in dough can affect viscosity (Chakraborty and Banerjee, 2009). The regression coefficients for viscosity of the extrudates are presented in Table 3 . The viscosity of the sorghum-Bambara groundnut extrudates was significantly $(\mathrm{p} \leq 0.05)$ influenced by the linear effect of extrusion temperature, the quadratic effects of feed moisture and extrusion temperature and the interaction effects of feed composition and feed moisture $(\mathrm{p} \leq 0.05)$, and feed moisture and extrusion temperature $(\mathrm{p} \leq 0.05)$. The coefficient of determination for viscosity of the sorghum-Bambara groundnut extrudates was 0.83 with a significant lack of fit. The curve showing the residuals against fitted values for the viscosity of sorghum-Bambara groundnut extrudates is presented in Figure 7(b). The observed and predicted values were observed to be reasonably close as can be seen in the residual plot in Figure 7(b). This is a validation of the suitability of the model in predicting these properties. The optimum viscosity of $12.0 \mathrm{Nsm}^{-2}$ was found at $21.1 \%$ feed composition, $22.5 \%$ feed moisture and $125^{\circ} \mathrm{C}$ extrusion temperature (Table 4). 


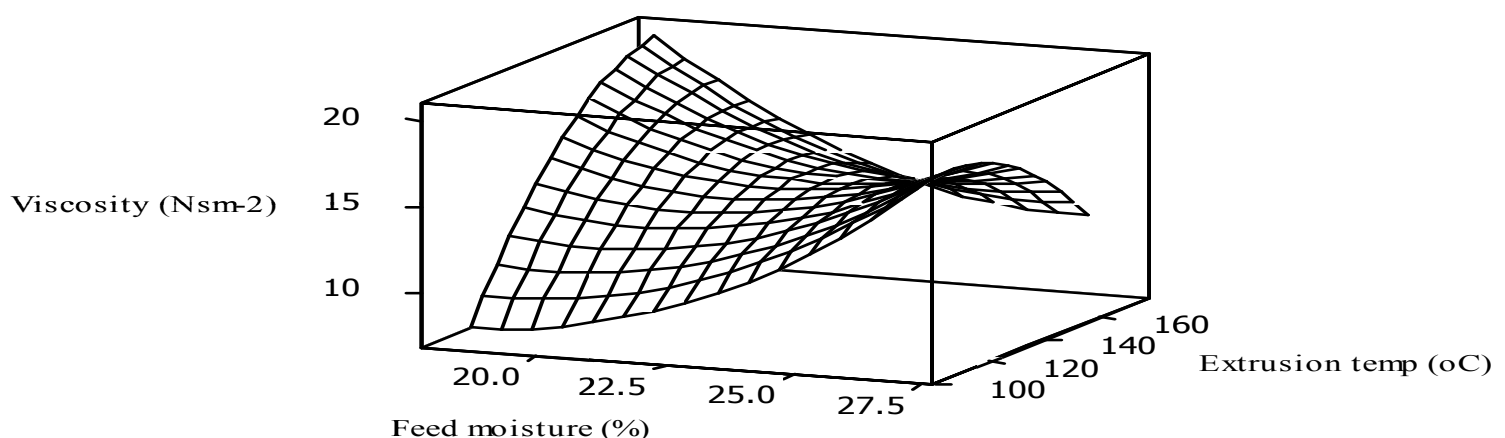

Figure 7(a). Effect of extrusion temperature and feed moisture on viscosity of sorghum-Bambara groundnut extrudates

Residuals Versus the Fitted Values

(response is VISCOSTY)

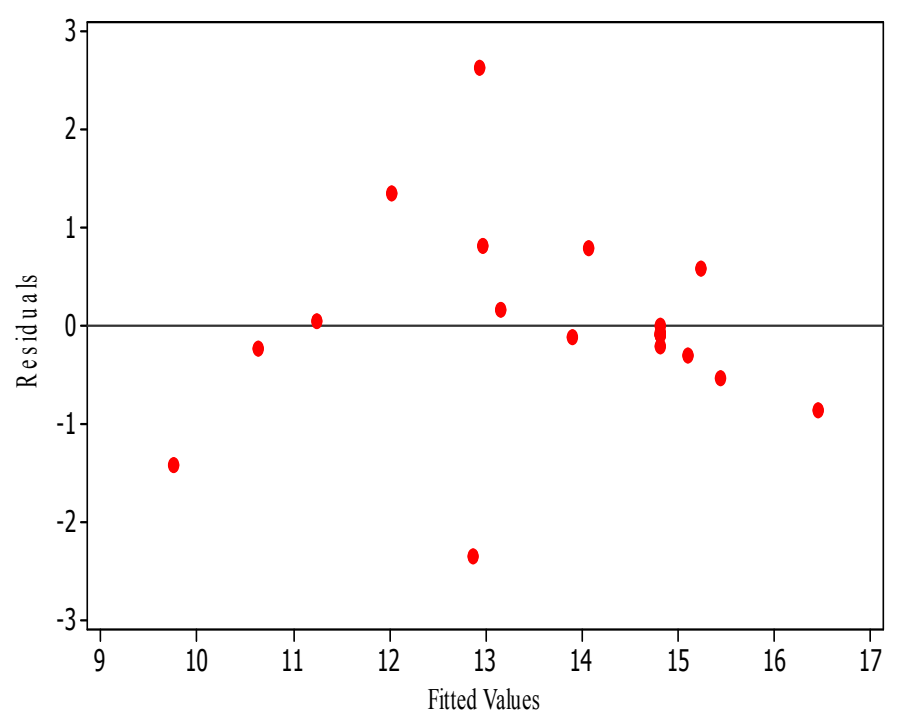

Figure 7(b). Residuals and fitted values of viscosity of sorghum-Bambara groundnut extrudates

\subsection{Photographic Responses of Extrudates}

The photographic responses of the extrudates are presented in plates B1 to B15. The plates show a comparative analysis of the bulk density and expansion ratio of the various samples. Sample B15 showed the highest expansion followed by sample B12. The details are contained in the footnotes. 
B1

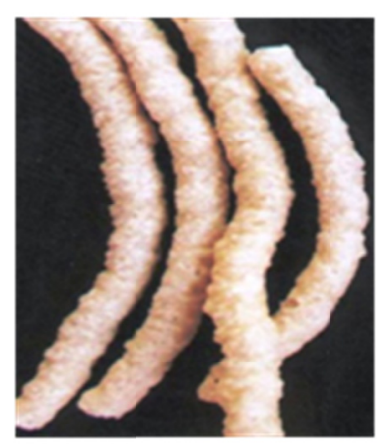

B5

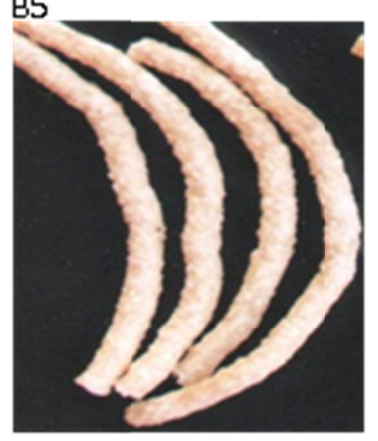

B9

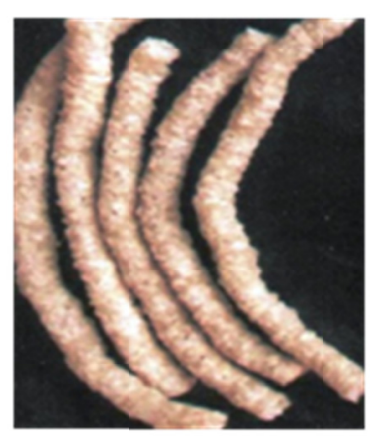

B13

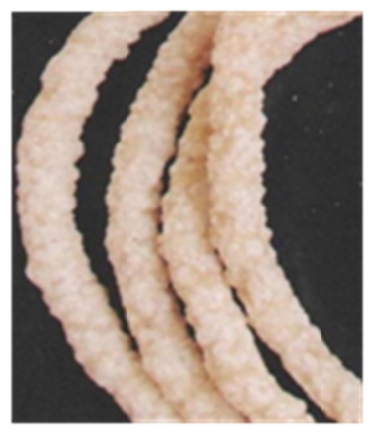

B2

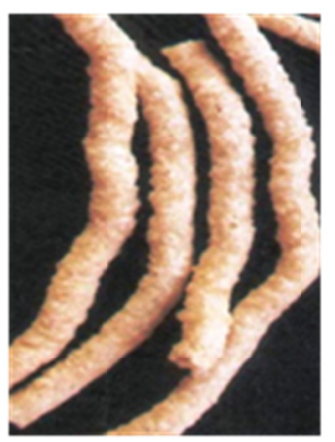

B6

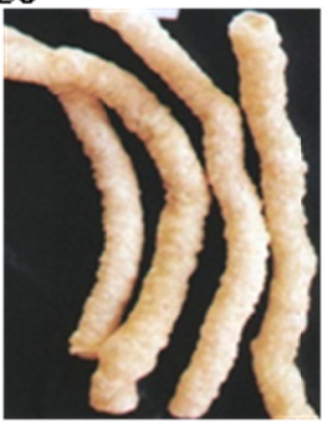

B10

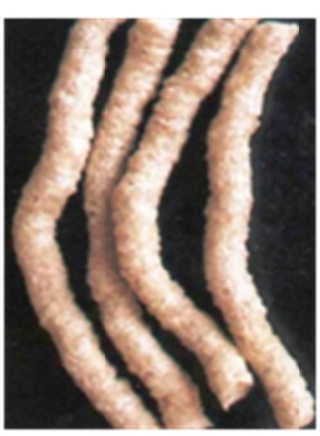

B14

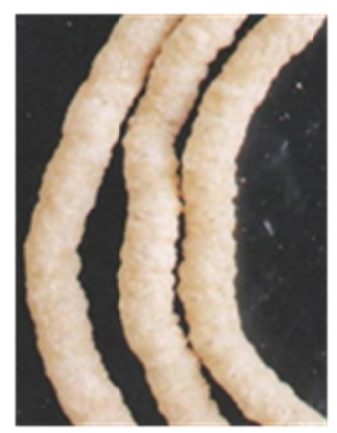

B3

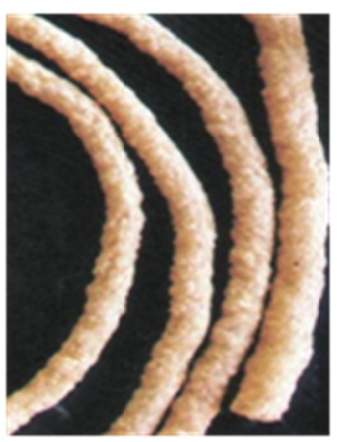

B7

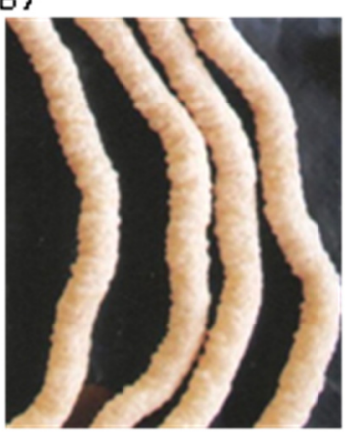

B11

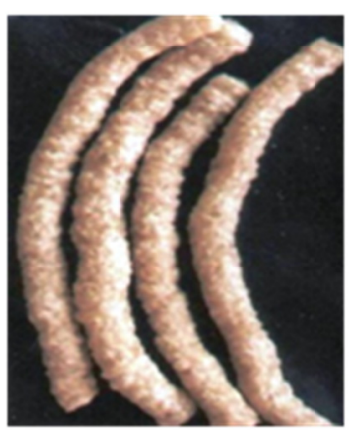

B15

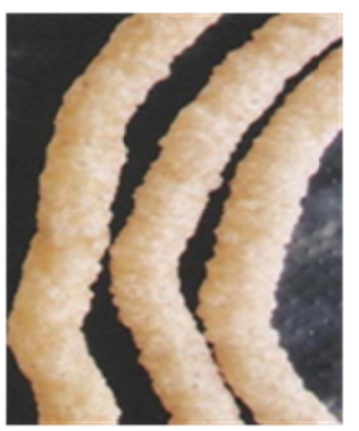

B4

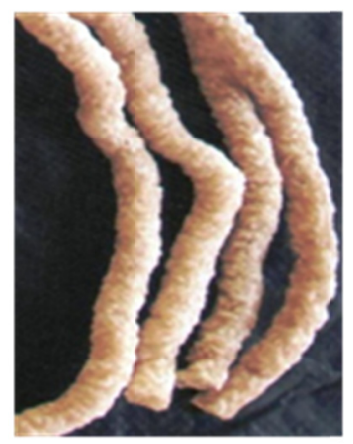

B8

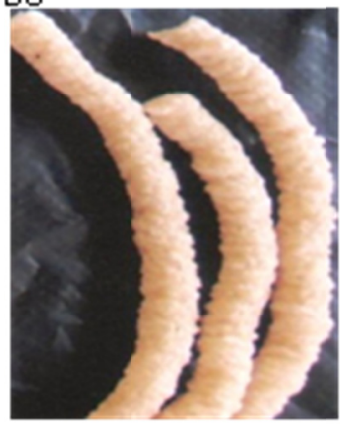

B12

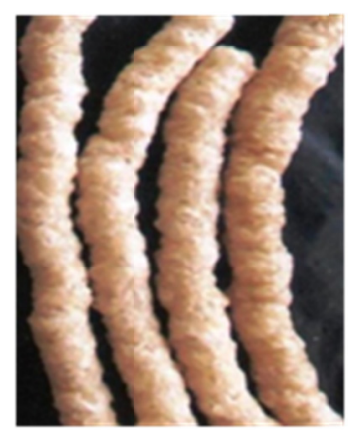

(B1) $10 \%$ Bambara groundnut, $20 \%$ moisture at $120^{\circ} \mathrm{C}$ (B2) $10 \%$ Bambara groundnut, $25 \%$ moisture at $120^{\circ} \mathrm{C}$ (B3) $20 \%$ Bambara groundnut, $22.5 \%$ moisture at $120^{\circ} \mathrm{C}$ (B4) $30 \%$ Bambara groundnut, $20 \%$ moisture at $120^{\circ} \mathrm{C}$ (B5) $30 \%$ Bambara groundnut, $25 \%$ moisture at $120^{\circ} \mathrm{C}$ (B6) $10 \%$ Bambara groundnut, $22.5 \%$ moisture at $140^{\circ} \mathrm{C}$ (B7) $20 \%$ Bambara groundnut, $20 \%$ moisture at $140^{\circ} \mathrm{C}$ (B8) $20 \%$ Bambara groundnut, $22.5 \%$ moisture at $140^{\circ} \mathrm{C}$ (B9) $20 \%$ Bambara groundnut, $25 \%$ Moisture at $140^{\circ} \mathrm{C}$ (B10) $30 \%$ Bambara groundnut, $22.5 \%$ moisture at $140^{\circ} \mathrm{C}$ (B11) $10 \%$ Bambara groundnut, $20 \%$ moisture at $160^{\circ} \mathrm{C}$ (B12) $10 \%$ Bambara groundnut, $25 \%$ moisture at $160^{\circ} \mathrm{C}$ (B13) $20 \%$ Bambara groundnut, $22.5 \%$ moisture at $160^{\circ} \mathrm{C}$ (B14) $30 \%$ Bambara groundnut, $20 \%$ moisture at $160^{\circ} \mathrm{C}(\mathrm{B} 15) 30 \%$ Bambara groundnut, $25 \%$ moisture at $160^{\circ} \mathrm{C}$. 


\section{Conclusions}

A ready- to- eat breakfast cereal with good water absorption properties and low viscosity was produced from sorghum-Bambara groundnut blends. Feed moisture had the most effect on the functional and physical properties followed by extrusion temperature. Increasing the feed moisture caused increases in WSI, BD and viscosity while decreasing the WAI and SEI. Increases in extrusion temperature caused corresponding increases in WAI and SEI but led to decreases in the MFR and viscosity. The optimum Bambara groundnut flour, feed moisture and extrusion temperature for the physical and functional properties were established in this study. Graphical residual analysis showed that observed values were in close agreement with the predicted values suggesting that the application of response surface methodology, with central composite face-centered design, could be a good approach to the development of breakfast cereals from sorghum-Bambara groundnut flour blends. The use of locally grown cereals such as sorghum and legumes like Bambara groundnut can make significant contribution to food security in the developing and the underdeveloped countries; most of which are located in sub-Saharan Africa.

\section{Acknowledgements}

This work was funded in part from the fellowship award of The Federal Polytechnic Mubi and the World Bank Assisted Science and Technology Education Post-Basic (STEP-B) Project (Credit No: 4304 UNI) of The Federal Polytechnic Mubi, Nigeria. Mr Ibok U. Ibok of the Department of Food Science Technology, Federal Polytechnic Mubi is most sincerely acknowledged for operating the extruder and other laboratory equipment used in this work.

\section{References}

Annor, G. A., Sakyi- Dawson, E., Saalia, F. K., Sefa-Dedeh, S., Afoakwa, E. O., Tano-Debrah, K., \& Budu, A. S. (2009). Response surface methodology for studying the quality characteristics of cowpea (Vigna unguiculata)-based tempeh. Journal of Food Process Engineering (pp. 1-20). http://dx.doi.org/10.1111/j.1745-4530.2008.00292.x

Alvarez-Martinez, L., Kondury, K. P., \& Harper, J. M. (1988). A general model for expansion of extruded products. Journal of Food Science, 53, 609-615. http://dx.doi.org/10.1111/j.1365-2621.1988.tb07768.x

Badau, M. H., Jideani, I. A., \& Nkama, I. (2006). Rheological behavior of weaning food formulations as affected by addition of malt. International Journal of Food Science and Technology, 41, 1222-1228. http://dx.doi.org/10.1111/j.1365-2621.2006.01189.x

Baladran-Quintana, R. R., Barbosa-Canovas, G. V., Zazueta-Morates, J. J., Anzaldria-Morates, A., \& Quintero-Ramos, A. (1998). Functional and nutritional properties of extruded whole pinto bean meal (Phaseolus vulgaris L.). Journal of Food Science, 63, 113-116. http://dx.doi.org/10.1111/j.1365-2621.1998.tb15688.x

Beuchat, L. R. (1977). Functional and electrophoretic characteristics of succinylated peanut flour proteins. Journal of Agricultural Food Chemistry, 25, 258. http://dx.doi.org/10.1021/jf60210a044

Brough, S. H., Azam-Ali, S. N., \& Taylor, A. J. (1993). The potential of Bambara in milk production and basic functionality systems. Food Chemistry, 47, 277-283. http://dx.doi.org/10.1016/0308-8146(93)90161-8

British Standard (BS). (1985). British Standard (812-103.1:1985), Now European Standards EN 933 (2012). Retrieved March 25, 2013 from http://en.wikipedia.org/w/index.php?title=mesh(scale)

Chakraborty, P., \& Banerjee, S. (2009). Optimization of extrusion process for production of expanded product from green gram and rice by response surface technology. Journal of Science and Industrial Research, 68, 140-148.

Ding, Q. B., Ainsworth, P., Tucker, G., \& Marson, H. (2005). The effect of extrusion conditions on the physicochemical properties and sensory characteristics of rice based expanded snacks. Journal of Food Engineering, 66, 283-289. http://dx.doi.org/10.1016/j.jfoodeng.2004.03.019

Egan, H., Kirk, R. S., \& Sawyer, R. (1981). Pearson's Chemical Analysis of Foods (8th ed.). Pub. Churchill Livingstone.

Enwere, N. J. (1998). Foods of Plant Origin: Processing and Utilization with Recipes and Technology Profiles, Afro-orbis Pub., Nsukka, Nigeria (pp. 59 -61).

Fellows, P. (2000). Food Processing Technology: Theory and Practice. New York: Ellis Horwood Pub. http://dx.doi.org/10.1201/NOE0849308871

Filli, K. B., Nkama, I., \& Jideani, V. A. (2013). The effects of extrusion conditions on the physical and functional 
properties of millet-Bambara groundnut based fura. American Journal of Food Science and Technology, 1(4), 87-101.

Filli, K. B., Nkama, I., Jideani, V. A., \& Abubakar, U. M., (2012). The effect of extrusion conditions on the physicochemical properties and sensory characteristics of millet-cowpea based fura. European Journal of Food Research and Review, 2(1), 1-23.

Filli, K. B., Nkama, I., Abubakar, U. M., \& Jideani, V. A. (2010). Influence of extrusion variables on some functional properties of extruded millet-soybean for the manufacture of "Fura": A Nigerian traditional food. African Journal of Food Science, 4(6), 342-352.

Goli, A. E. (1997). Conservation and Improvement of Bambara groundnut (Vigna subterranean [L.] Verdc.). In Heller et al. (Eds). Bibliographical Review: Proceedings of an International Workshop Held at Harare, Zimbabwe, IPK/IPGRI (pp. 4-10).

Gomez, M. H., Waniska, R. D., Rooney, L. W., \& Lusas, E. W. (1988). Extrusion cooking of sorghum containing different amounts of amylose. Journal of Food Science, 53(6), 1818-1822. http://dx.doi.org/10.1111/j.1365-2621.1988.tb07850.x

Jackson, D. S., Gomez, M. H., Wansika, R. D., \& Rooney, L. W. (1990). Effects of single-screw extrusion on starch as measured by aqueous high performance size exclusion chromatography. Cereal Chemistry, 67, 529-532.

Karikari, S. K., Wigglesworth, D. J., Kwerepe, B. C., Balole, T. V., Sebolai, B., \& Munthali, D. C. (1997). Country Reports: Botswana. In: Heller et al. (Eds.), conservation and improvement of Bambara groundnut (Vigna subterranean) [L.] Verdc.) Proceedings of an international, workshop held at Hrare, Zimbabwe. IPK/IPGRI (pp. 11-19).

Kebede, L., Worku, S., Bultosa, G., \& Yetneberk, S. (2010). Effect of extrusion operating conditions on the physical and sensory properties of tef (Eragrostis tef [Zucc.] Trotter) flour extrudates. EJAST, 1(1), 27-38.

Lewis, M. J. (1987). Physical Properties of Food and Food Processing Systems, England: Harwood Int. Pub. in Sci. and Tech.

Malcolmson, L. J., Matsuo, P. R., \& Balshaw, R. (1993). Textural optimization of spaghetti using response surface methodology: Effects of drying temperature and durum protein level. Cereal Chemistry, 70, 417-423.

Mkandawire, C. H. (2007). Review of Bambara Groundnut (Vigna subterranean (L) verde). Production in Sub-Sahara. African Agricultural Journal, 2(4), 464-470.

Mercier, C., \& Feillet, P. (1975). Modification of carbohydrate components by extrusion cooking of cereal products. Cereal Chemistry, 52, 283.

Molina, M., Braham, J. E., \& Bressani, R. (1983). Some characteristics of whole corn: whole soybean (70:30) and rice: whole soybean (70:30) mixtures processed by simple extrusion cooking. Journal of Food Science, 48, 434-437. http://dx.doi.org/10.1111/j.1365-2621.1983.tb10759.x

NFRA. (2008). Agricultural Productivity Survey, 2007 Survey Report, Federal Ministry of Agriculture and Rural Development, Abuja, Nigeria.

Nicole, M., Fei, H. Y., \& Claver, P. (2010). Characterization of ready-to-eat composite porridge flours made by soy-maize-sorghum-wheat extrusion cooking process. Pakistan Journal of Nutrition, 9(2), 171-178. http://dx.doi.org/10.3923/pjn.2010.171.178

NIST/SEMATECH (2006). Engineering Statistics. e-Handbook of Statistical Methods. Retrieved July 6, 2007, from http://www.itl.nist.gov/div898/handbook

Nkama, I. (1994). Traditional methods of production of high protein energy foods from grain legumes in the north-eastern states of Nigeria. Annals of Borno (pp. 138-148).

Nwabueze, T. U., \& Iwe, M. O. (2006). Mass flow rate, nutrient composition and some functional properties of single screw extruded African breadfruit (Treculia africana) blends. Journal of Food Technology, 4(1), $50-58$.

Ocran, V. K. (1998). Seed Management Mannual for Ghana. Accra, Ghana: MOFA.

Oguntunde, A. O. (1985). Development of New Food Products from readily Available Raw Materials. Paper presented at the Nigerian Institute of Food Science and Technology Training Workshop. Ibadan, Nigeria. 
Oke, M. O., Awonorin, S. O., Sanni, L. O., Asiedu, R., \& Aiyedun, P. O. (2010). Effect of extrusion variables on extrudates properties of water yam flours- a response surface analysis. Proceedings of 11th ISTRC-AB Symposium, Kinshasha, DR Congo. 4-8th October, 2010.

Oladele, A. K., \& Aina, J. O. (2007). Chemical composition and functional properties of flour produced from two varieties of tiger nut (Cyperus esculentus). African Journal of Biotechnology, 6, 2473-2476.

Olapade, A., \& Adetuyi, D.O. (2007). Comparison of different methods of producing Bambara (Voandzeia subterranean L. Thou), flours for preparation of moin-moin. Nigerian Food Journal, 25(2), 150-157.

Pelembe, L. A. M., Erasmus, C., \& Taylor, J. R. N. (2002). Development of a protein-rich composite sorghum-cowpea instant porridge by extrusion cooking process. Lebensmittel Wissenschaft Und-Technologie, 35, 120-127. http://dx.doi.org/10.1006/fstl.2001.0812

PROTA (Plant Resources of Tropical Africa). (2006).Cereals and pulses. In M. Brinkand G. Belay (eds.). PROTA Foundation Wageningen, Netherlands (pp. 213-217).

Qing-Bo, D., Ainsworth, P., Tuker, G., \& Marson, H. (2005). The effect of extrusion conditions on the physicochemical properties and sensory characteristics of rice-based expanded snacks. Journal of Food Engineering, 66, 284-289.

Shobha, V., Kasturiba, B., Rama, K. N., \& Nirmala, Y. (2008). Nutritive value and quality characteristics of sorghum genotypes. Karnataka J. Agric. Sci., 20, 586-588.

Suknark, K., Philips, R. D., \& Chinnan, M. S. (1997). Physical properties of directly expanded extrudates formulated flour and different types of starch. Food Research International, 30(8), 575-583. http://dx.doi.org/10.1016/S0963-9969(98)00016-7

Suknark, K., McWatters, K. H., \& Phillips, R. D. (1998). Acceptance by American and Asian consumers of extruded fish and peanut snack products. Journal of Food Science, 63(4), 721-725. http://dx.doi.org/10.1111/j.1365-2621.1998.tb15822.x

United States Department of Agriculture (USDA). (2015). Sorghum Production by Country. Index Mundi, 2016.

Zasypkin, D. V., \& Tung-Ching, L. (1998). Extrusion of soybean and wheat flour as affected by moisture content. Journal of Food Science, 63(6), 1058-1061. http://dx.doi.org/10.1111/j.1365-2621.1998.tb15854.x

\section{Copyrights}

Copyright for this article is retained by the author(s), with first publication rights granted to the journal.

This is an open-access article distributed under the terms and conditions of the Creative Commons Attribution license (http://creativecommons.org/licenses/by/3.0/). 